\title{
Czechs in Poland in the 19th and 20th Century and Their Influence on the Development of Polish National Music
}

\section{Magdalena Dziadek}

It is a well-known fact that a lot of Czech musicians worked in Poland in the $18^{\text {th }}$ century and the first half of the $19^{\text {th }}$ century. They were German-speaking and typically took the positions of directors, orchestra musicians and teachers in private or public institutions. They were held in high esteem on the professional grounds. However, over the years their influence on the development of Polish national music remained vague, which was to change only with the appearance of two illustrious individuals: Jan Stefani and Wilem Würffel.

Jan Stefani, the musical director at the court of the last Polish king Stanislaw August Poniatowski, later the director of the National Theatre in Warszawa is considered to be the author of the first Polish national opera. It was staged in 1794 under the title Cud mniemany czyli Krakowiacy i górale [The Pretended Miracle or Krakovians and Highlanders] and represented the so called idyllic opera, taking place in a rural setting. When it comes to its music style, it combined the style of Mozart with the use of some elements taken from Polish national music, such as the motifs typical of Polish national dances: mazur, polonaise and krakowiak.

Wilem Würffel, the pupil of Václav Jan Tomášek, worked in Warszawa as a piano teacher from 1815 . He is the author of several polonaises published in Warszawa, but the most important trace of his ties with Polish national music is Grande fantaisie lugubre au souvenir des trois héros Prince Joseph Poniatowski, Kościuszko, et Dabrowski, composé et dediée à la nation polonaise (Warsaw, 1818). The composition expemplifies a genre of fantasias flourishing in Poland at that time; its characteristic feature was the use of narrative elements and quotations to express Polish nationalism. Würffel illustrated, among others, the sounds of the bells from the famous Polish churches and put a quotation taken from the patriotic anthem Mazurek Dabrowskiego (nowadays, it is the Polish national anthem). One can also point out the similarity between Würffel's polonaises, 
belonging to the German polonaise tradition, and the early polonaises by his most famous pupil Frederic Chopin (let me explain, at this point, that there are some musicial features that act as an objective criterion according to which one can decide if a polonaise belongs to the German tradition; one of them is the lack of the so called Polish cadenza. As the Polish language, with very few exceptions, has fixed stress on the penultimate syllable (last but one syllable), the formula of Polish cadenza cadenza consists of two units, shorter and longer, included in three parts of the last bar.

The reconstruction of the further history of the influence of Czechs on Polish national music must take into consideration the fact that after the partitions of Poland fundamental differences arose between the areas of the country remaining under the rule of the particular foreign powers: Russia, Austria and Prussia. The Austrian part called Galicia was multicultural and inhabited by many Czech citizens. Moreover, the neighbourhood of the Galician centers and Prague enabled and fostered an unbroken cultural exchange between them. As regards the Prussian part, the local elites and the Czech elites shared the same political interest, namely the resistance against the supremacy of the Germanic elements in politics and culture. By contrast, the Russian part with its two capitals, Warszawa and Vilnius, was distant to Czech affairs in a double sense. First of all, the distance was geopraphical. Second of all, the general attitude of Czechs and Poles towards Russia was different. Because of their anti-Russian sentiment, Poles did not support slavophilism, being an essential element involved in the awaking of Czech national consciousness. Such a state of affairs can be perfectly illustrated by the story of the Czech ethnographer Ludvík Kuba, who visited famous Polish ethnographer Oskar Kolberg in the summer of 1886, on his way to Russia. During the visit, Kuba participated in Kolberg's conversation with the owners of the house in which Kolberg rented an apartment. Kuba noted the touchy tone of the conversation, which included many remarks on the Russian despotism, manifested, among others, by the ideology of Pan-Slavism. The Czech guest felt awkward, and he commented as follows: "Being a greenhorn and overwhelmed by similar feelings towards Poles and Russians, I could hardly join the conversation" ${ }^{1}$. Because discussing the Polish-Czech relations in the musical life of all the three parts of Poland would be too extensive, I will limit myself to reporting these relations on the example of Warszawa, a decision-making center, acting as a mental and spiritual capital of the non-existent country.

The state of Polish-Czech relations in the middle decades of the $19^{\text {th }}$ century is well-reflected in the following relation of an anonymous Czech, who traveled from St. Petersburg to Prague in the summer of 1859. His account was published

1 Ludvik Kuba, Cesty za slovanskou pisní (Prague 1953), 90. 
in Pražské noviny: “Sbližování se Poláků k jiným slovanským plemenům je posud malé, jest ale přece. Slyšel jsem tam např. deklamovat Malczewského 'Marii' $\mathrm{v}$ českem jazyku, i zpívati 'Těšme se blahou nadějí'v překladu polském, který já však mám za originál. Škoda, že knihkupecké a vůbec obchodní spojení s Čechy jest tak mizerné. [Poles are hardly close to other Slavic tribes, but I have heard, for example, how Malczewski's Maria was recited in Czech and Těsme se blahou nadèji sung in the Polish translation, which I consider to be the original. It's a pity that collaboration with the Czechs, commercial and any other, is so miserable here.]"2

I must add that Maria is the famous poem written in 1825 by Antoni Malczewski, a poet belonging to the so-called ukrainian school of Polish poetry. The subtitle of Maria is "A Ukrainian novel", which is worth to remind against the backdrop of the well-known Czech-Ukrainian sentiment flouorishing in the 19 th century. However, we should ask whether the translation made by the above Czech poetry admirer was based on the Polish original text or on its German translation published as early as in 1845 .

Anyway, the relation of the unknown author suggests that a small minority of Czech intelectuals and artists lived in Warszawa at that time and that they organized some meetings with their Polish friends. Perhaps those meetings resembled besedas. Yet the Polish press did not mention the event of the Czech Beseda in Warszawa before the turn of the $19^{\text {th }}$ and $20^{\text {th }}$ centuries.

We also have another exciting testimony of Polish-Czech cultural discours from about the same period as the relation of an anonymous artist. It is a novel titled Black Ribbon and published in 1852 by the well-known writer Włodzimierz Wolski, who was the member of literary group "Warszawa Bohema" (nowadays, Wolski is primarily recognized as the author of libretti to Moniuszko's Halka and Hrabina / The Countess). Black Ribbon is a roman à clef. Some real prominent figures of Warszawa music life were showed in it - Stanisław Moniuszko, a composer; Józef Sikorski, a prominent critic; Maria Kalergis, a host of a famous music salon; and many other bigwigs. In his novel, Wolski quoted, of course in a literary manner, a number of authentic discussions that took place in Warszawa at that time. One of them concerned the project of Slavic opera. The author's footnote reveals that Wolski heard about the above project from a Czech settled in Warszawa whose name was Wilczek (who may be identical to the pianist and composer Felix Wilczek, actually living in the city at the time). The project was typical of Czechs but very unusual of Poles. First of all, Wolski described Slavic music according to the theory of national styles, assuming some standard characteristics of German, French, Italian and Slavic music (in his taxonomy,

2 “Feuilleton. Z Petrohradu”, Pražske noviny, 28 August 1859, 200. 
German music makes the listeners think, dream and miss; French music makes the listeners float and think; Slavic music makes the listeners feel, dream and miss; Italian music does not make the listeners think at all). Then, Wolski depicted Wilczek's project of the Slavic opera. It concerned a 5-act work called The False Tsar Dimitri whose action was to take place in three Slavic countries: Russia, Poland and Ukraine (strictly speaking - in Kraków, Wiśniowiec, Moscow and an unspecified place in Ukraine). The plot was devised as a pretext to apply the elements of Russian, Ukrainian and Polish national music characteristic of three social strata: noblemen, folk people and clergy. The nobility was to be represented by Polish dances: mazur and polonaise, folk people - by songs symbolizing three nationalities living in Poland (Polish krakowiak and oberek; Ukrainian kolomyjka and dumka; and a Lithuanian song. Church matters were to be illustrated by the introduction of some elements the liturgy of the Orthodox and Catholic Church. Wolski's project, focused on the creation of universal Slavic music, was an isolated phenomenon, a document utterly uncharacteristic of the Polish literature of the mid-nineteenth century. Taking into account the political situation and atmosphere in Warszawa around 1850, it is surprising that Wolski did not hesitate to include some bits of Russian musical tradition in his project; it was even bolder of him to use the events form the history of Russia in the plot. However, as I said, it can be explained by the fact that the primary author of the project was of $\mathrm{Czech}$ origin.

One more thing is worth emphasizing here: the above documents concerning Polish-Czech ralations in music are literary and not musical sources. It is because in the $19^{\text {th }}$ century the innovative aspects of Polish music culture were shaped under the influence of literature; literary discourse, continued by critics, was far ahead of musical practice. I have already explained that phenomenon on the example of Polish reception of Wagner's music in several scholarly papers published in Poland, Great Britain and Ukraine. The principles governing the Poland reception of the works by Smetana and Dvoŕák were roughly the same.

The first Polish critic interested in Smetana and his music was Jan Kleczyński, active since the early 1870s. In the second half of 1874, he published the article entitled "Sprzedana narzeczona" (Bartered bride ${ }^{3}$ ). It was the first Polish study devoted to Smetana. One should ask, how Kleczyński, who had not been to Prague and heard Smetana's opera before, took the idea of writing such an article? To answer such a question, one must tackle another critical issue: the issue of circulation of ideas between Western and Central Europe. Shortly before the publication of Kleczyński's paper, a comprehensive article on Smetana appeared in Leipzig in Allgemeine musikalische Zeitung. The magazine was available in

3 Jan Kleczyński, “Ruch muzyczny”, Bluszcz, no. 44 (1874): 350-351. 
Warszawa, like many other foreign magazines that were systematically studied by Polish authors and used as guides in the matters of international musical life. Thus, the development of local musical concepts was shaped by the reception of musical ideas created in Western Europe. Paradoxically, this also applied to the approaches towards the music of Slavic nations. Due to the authority of Western critics, their opinions about Slavic music were considered as valid. The intellectual mechanism, consisting in the use of German critical filter by Polish musical critics to build the image of Czech music, can be perfectly illustrated by the further history of the Polish reception of Smetana. Its first chapter belonged to Kleczyński. Having become a consistent admirer not only of Smetana but also Czech music in general, he wrote the first Polish composition based on Czech (strictly speaking, Moravian) folk melody, entitled Shodovani se (Resignation). Between 1880 and 1895 Kleczyński published his periodical Echo Muzyczne $i$ Teatralne. Several issues of that magazine concerned various facets of Czech and Slavic music, including the publication of the piece based on Shodovani se. The magazine also devoted a lot of space to the celebration of the opening of the National Theatre in Prague in 1883; Kleczyński was present at the ceremony.

To reconstruct inflow of ideas on Czech music from the Wester Europe to Polish critical thought, one should first mention the famous Viennese critic Eduard Hanslick and his harsh views on Polish music after Chopin. In 1893, Hanslick reviewed the monograph concert of Władysław Żeleński in Vienna and formulated the following opinion: "Chopin was the last brilliant and significant Polish composer. Moniuszko may have been gifted, but he never crossed his country's borders to win European acclaim. And there is only silence after him. Czechs and Russians have recently gained a great advantage in music over Poles"4. The above mentioned concert of Żeleński's music was designed as rehabilitation after the defeat suffered by Polish opera performances at the famous theater and music exhibition held in Vienna in the early autumn of 1892.

For its participants, the exhibition was the occassion for discussing the current state of national music cultures in the region and for setting some directions for their future development. In practice, however, it was a platform for sharp Slavic-German confrontation. As in the case of the Prague Slavic Congress of 1848 , it revelad bitter conflicts of interests between the particular Slavic nations. However, what was the source of the great success of Czech music, represented by Bartered Bride, and what stood behind the flop of Moniuszko's operas: Halka and The Haunted Manor, which were performed during the exhibition? This was the central question asked in Poland after the event. Interestingly enough, the optimistic mood had prevailed before. The oustanding Varsavian critic Aleksander

4 Eduard Hanslick, "Feullieton. Conzerte”, Neue Freie Presse, no. 10251 (1893): 2. 
Poliński was its proponent, and he used a very characteristic argument, referring to the positive reaction of Germans to Czech proposals:

Until the performances of the Czech theater, it was feared that the melodies in Moniuszko's operas have too much Slavonic otherness and sentimentality to meet the taste of the Viennese audience. These fears were quickly dispelled by the triumphs of the Czech theater [...]. The cordial reception of the Slavic national opera by the Germans seems to bode well for our future performances 5 .

As a result, Poles were completely surprised by the negative attitude towards their offer by the leading Viennese critics, Eduard Hanslick ${ }^{6}$ and Theodor Helm ${ }^{7}$. Various explanations were provided, among others, poor level of Polish performances and the aversion of the Germans resulting from nationalism. Some objective observers wrote that Moniuszko's music was outdated and naïve, pointing out its failure to comply with the canons of contemporary $\operatorname{art}^{8}$. The backwardness of Polish musical culture was also used as a general argument. In this context, the comparison with Czech culture appeared again. It was presented as strong, vivid and rational, consistently striving to take its rightful place in the European music culture. The unknown author wrote in the feminine magazine Bluszcz:

You need to know Czechs and their situation in order to understand how and why it thrills them with joy whenever they are appearing and gainining international recognition, whenever ones talk and write about them. This feeling is more profound and more tender than mere vanity, than the desire for applause. They also try to develop their strength in the field of art to enable Czech art to exist, to occupy a place among the nations and to earn the interest of Europe. That is why Czechs are so busy with theater. They want originality; they want their own school for their Divadlo?.

5 Aleksander Poliński, “Mozaika wiedeńska”, Tygodnik Ilustrowany, no. 142 (1892): 181.

6 See: Ed[uard] H[anslick], "Musik- und Theater-Ausstellung. Die polnische Oper in AustellungsTheater”, Neue Freie Presse, no. 10077 (1892): 5.

7 See: Helm Theodor, "Von der Internationalen Musik- und Theater Ausstellung (Schluss)", Musikalisches Wochenblatt, no. 46 (1892): 566.

8 See: [Bylicki Franciszek], Die Musik in Polen, [...] Skizzen [von Franz Bylicki und Alfred Szczepański] (Wien 1892). About thee choes of the Viennese exhibition in Poland see also: Magdalena Dziadek, "Echa prasowe występów opery lwowskiej na Wystawie Muzyczno-Teatralnej w Wiedniu w 1892 roku”, Musica Galiciana (2008), 39-48.

9 “Z Czech”, Bluszcz, no. 25 (1892). 
The author of the above text was probably the Czech writer Eduard Jelínek, who cooperated with Warszawa journalistic environment at that time.

The matters related to the organization of musical life and to the state of contemporary music culture became the leitmotif of the Polish discussion on Czech music in the next decades. Critics very rarely compared Polish and Czech music as such, and even these infrequent attempts were limited to persistent comparison Bartered Bride and Halka, considered as flagship works of national art of both countries. Władysław Bogusławski, a Varsovian critic, gave a fascinating remark on the issue. In 1896, he wrote that in his Bartered Bride Smetana adopted a relatively new and original approach to a genre of comic opera, while Halka was only the implementation of the well-known convention. This statement, however, was unique. Usually, both works were simply placed side by side as examples of Slavic operas.

Despite the favourable reception of Smetana's opera in the late 19th century, it proved challenging to stage Bartered Bride in Warszawa. One of the reasons was the fact that Tchaikovsky's operas entered the same stage at that time. Let's mention here, that one the greatest paradoxes concerning Warszawa musical life at the turn of the $19^{\text {th }}$ and $20^{\text {th }}$ centuries was the great success of Tchaikowski's music. He quickly became the Varsovian's favourite composer, and such a state of affairs was to last until 1939. One even spoke about "czajkowskomania" of the Varsovian audience. Tchaikovski's works were received in Warszawa as examples of both Russian music and international repertoire. Their great public success was associated with their purely artistic features, so they did not sharpen the appetite for other Slavic works.

The way of Czech operas to the Varsovian stage was long. As early as in 1873, a year after Stanisław Moniuszko's death, Smetana sent the score of Bartered Bride to Sergey Muchanow, the president of the committee of governement theaters in Warszawa, but he did not receive any answer. In fact, Bartered Bride was premiered in Warszawa as late as in 1895 in an operetta theater called Teatr Letni; Dalibor came on the stage of the Grand Theatre in 1902. The performance of Bartered Bride was a reasonably great success thanks to the cooperation with A. Berger, a choreographer from Prague, who composed a series of Czech dances, presented during the spectacle. By contrast, Dalibor came off the poster quite quickly. After the presentations, several popular publications appeared, containing easy transcriptions of favourite fragments of both Smetana's operas. Besides, the libretto of Dalibor was printed. In those days also some small Dvořák's works were published in Warszawa, among them Valse op. 54 no. 1 and - of course Humoresque. Warszawa library collections inlcude also Dvořak's small pieces published in Germany. The entry of his serious works: symphonies and chamber 
compositions entered the stage in Warszawa several years later, not only because of the lack of professional orchestral and chamber ensembles in the capital of the Polish Kingdom but also due to the dislike of Czechs, rapidly growing from the beginning of the 20th century and motivated by political controversies (which arose mainly from the Czech support for the Ukrainians in the AustroHungarian parliament).

The interest of Varsovians in Czech was greater rose a little in 1908 - the year of the Neoslavonic Congress in Prague - and it was an evident result of the then atmosphere of general interest in the "Slavic matter". It was sparked, once again, by the press publications. In 1908, a Czech publisher Miroslav Kropánek entered with the article, encouraging Poles to become interested in Czech music, in the opinion-making weekly Tygodnik Ilustrowany ${ }^{10}$. In the same year, Adolf Nowaczyński published in the daily Nowa Gazeta article "Contemporary Czech music"11, which contained an appeal to the organizers of Polish musical life to perform more Czech flagship works. In response to these appeals, Grzegorz Fitelberg - the artistic director of the Warszawa Symphony Orchestra who worked at the Warszawa Philharmonic in 1909-1911 - organized in 1909 the first monographic concert of Czech music, filled with works by Smetana, Dvořák and Fibich. The next Czech concert in Warszawa took place in 1911, also under the direction of Fitelberg. In the program, apart from Smetana and Dvořák, Vítězslav Novák appeared. Young musicologist Adolf Chybiński wanted to establish closer contacts with the Czech musical environment in Prague. He made some efforts to include the works of the leading Polish musicians: Szymanowski, Opieński, Fitelberg and Różycki to the programs of Umělecká Beseda. However, these efforts were unsuccessful ${ }^{12}$. The author, who was critical of his compatriots, wrote that they "wasted" Chopin's heritage. In opposition to this phenomenon, he pointed to the way in which Russians and Czechs, among them Smetana, drew from Chopin:

Solemn ceremonies were held in honor of the Master; celebrations were arranged, his heart was brought to his homeland, but [Poles] did not want to feel and create in consonance with that big heart. [...] Chopin was treated differently by our brothers, Czechs and Russians. The great creator of Bartered Bride, an opera still played in Germany, who in our country fell into shameful oblivion, belonged to the first Chopinists. Already before 1860, he published piano works stylised in Chopin's manner, and

${ }_{10}$ Miroslav Kropánek, “Najnowsza muzyka czeska”, Tygodnik Ilustrowany, no. 36 (1908): 740.

${ }^{11}$ Adolf Nowaczyński, “Dzisiejsza muzyka czeska”, Nowa Gazeta, no. 498 (1908): 500.

12 See the letter of Adolf Chybiński to Ludomir Różycki sent from Kraków 20 January 1911. Published in: Res Facta (1982): 318. 
he wanted to create Czech national polkas in the same way that Chopin showed in his mazurkas, clearly stating that he was inspired by Chopin ${ }^{13}$.

In his later articles, published in the Slavonic World - the organ of Slavic Club in Kraków, founding after the Neoslavic Congress in Prague in 1908, Chybiński made several further comparisons between Polish, Russian and Czech musical cultures, trying to demonstrate the advantage of neighboring countries over Poland ${ }^{14}$. Here we can see that once again, that Polish discussion on Czech music was limited to practical matters; the artistic questions remained virtually untouched. This state of affairs was also characteristic of the interwar period.

After the end of the Czechoslovakian-Polish border conflict (1920), Poland started striving for political and cultural rapprochement to Prague. This was justified by the new situation of the country as a part of the constellation of the newly created states of Central Europe. Some Polish politicians tried to impose the vision of Poland as a new leading power in this region. Less popular, but also present in the Polish politics of those years was the attempt to establish close cooperation between the new states, inspired by economic matters and, at least when it came to cultural life, Slavophilism.

This orientation remained, as previously, attractive primarely to the citizens of Poznan - the former capital of the Prussian segment of the partitioned country. Some important initiatives concerning the participation of Polish musicians in musical events organized in Czechoslovakia have emerged from Poznań. These were, for instance, festivals organized by the International Musical Society or choir meetings. Apart from Poznań, Warszawa contributed to the PolishCzechoslovakian bilateral cultural cooperation. This was due to its new role as the capital of the country. Between 1920 and 1937, many official events were organized there devoted to solemnize some important Czechoslovakian anniversaries (I have reported about them in detail in my paper titled "The Czechoslovakian Music in Poland in the Interwar Era", published in Czech and Slovak Journal of Humanities. Musicologica in 2017). Various festivals, concerts and opera performances were held or staged by musical institutions with the help of governmental organizations. The government supported also publications of some materials about Czech music. For example, in 1933, Polish Ministry of Foreign Affairs financed the publication of the first Polish monograph about Smetana, written by Franciszek Brzeziński on the occasion of the 50th anniversary of the death of the Czech composer. Also, many private people were engaged in creating Polish-Czech cultural exchange. There were among them Czech singer

13 Adolf Chybiński, "Chopin - Moniuszko i ich stanowisko w muzyce polskiej”, Sfinks, vol. 3 (1908): 472-3.

${ }^{14}$ Eg. Adolf Chybiński, “Muzyka polska wśród słowiańskiej”, Świat Stowiański, no. 38 (1908). 
and director Józef Munclinger, who cooperated in several initiatives connected with presentation Czech operas in Warszawa, Lwow and Poznań, as well as Pole Marian Szyjkowski, who was appointed as the first head of the Institute of Polish Philology at the Charles University in Prague, established in 1923 and starting from that time was busy organizing Polish-Czechoslovakian exchange in literary, theatrical and musical life.

In spite of their great efforts, institutions and private individuals failed to make Czech music a permanent part of musical life in Poland. Its dissemination has remained, at best, partial. Moreover, it proved hard for new Czechoslovakian music to gain wider acceptance in local concert halls. The reason was the same as before the Great War - Czech composers were simply losing competition with the prominent Russians, whose works not only often resounded on Polish stages but also inspired multiple Polish composers. Especially Stravinsky and Prokofiev took the position of the chief patrons of Polish neoclassicism, the current prevailing among the Polish composers of the era.

The only case of increased interest in newer Czech music concerned Leoš Janáček, or, more precisely, his opera Jenífa, which was staged in the 1920s in Warszawa, Lviv and Poznań. However, in this case, inspiration also came from Western Europe. The performance of Janáček's opera in Poland should be associated with the influence of the personal legend about the composer, which was created in Germany by, among others, Max Brod - the discoverer and admirer of the Janáček ${ }^{15}$. Some Polish recipients of Janáček's music must have been interested also in his other works. In the National Library in Warszawa, I have found a copy of his piano collection "In Nebel", printed in Prague by Umělecká Beseda in 1924.

As I showed in my other paper, devoted to Polish reception of Janáček's mu$\mathrm{sic}^{16}$, the ways of rendering Janáček's music in the context of modern folklorism were borrowed - as usual - from the Western, mostly German, critical works.

The report about the influence of Czech music on Polish should be supplemented with a piece of information about modern Polish compositions based on Czech themes. The most notable examples here are the works created in the early 1940s by Jan Maklakiewicz, one of the disciples of Karol Szymanowski. In 1947, Polish Music Publishing House edited his Uwertura "Praska" [Prague overture] for orchestra and a cycle of songs for voice and piano to the Czech text by Ladislav Stehlík entitled "Madoně” (parts: Krumlovská, Lnářská, Zlatokorunská). In 1947, Maklakiewicz composed (but never published) also three songs to the

15 About Max Brod as Janáček's admirer see: Michał Jaczyński, “Max Brod as Music Critic”, Musicologica Olomucensia, no. 23 (2016): 81-100.

${ }^{16}$ Dziadek Magdalena, “The Reception of Leoš Janáček's Output in Poland in the 19th and 20th Centuries (until 1956)", Czech and Slovak Journal of Humanities. Musicologica, no. 2 (2015): 11-19. 
words of A. Trýba's poem entitled Loňské listí, not published. Unfortunately, these compositions have not attracted Polish musicologists' attention so far.

The Czech thread occured also - in a legendary form and with the addition of the propaganda content typical of the early 1950s - in the ballet Rapsod created by the most prominent Polish composer of the stalinist era Piotr Perkowski. The premiere of Rapsod took place at the Silesian Opera in Bytom in 1950. Stefan Otwinowski, the author of the script of this piece, summarized its course: "Fabulous poetic legends reveal the truth about the emergence of societies. Lech, Czech and Rus - three brothers - lead their ranks. They pay tribute to the earth. Work begins. Friendship, order and joy are born from this work. Ill advice comes from strangers. The ferment begins in a solidary group. The exploiter class colludes and breaks Slavic unity." ${ }^{17}$ The ballet also personifies capitalism, as hostile to the Slavs.

The next (and the newest) Polish composition drawing on Czech music, which I am able to indicate is the duet Setkáni s plamenem mistra Jana Husa. It was written in 2006 by Ryszard Gabryś, a Silesian composer who originates from Cieszyn, the city located on the Polish-Czech border. In this case, the inspiration was connected with the Protestant confession of the author and with his purpose to propagate the cultural traditions of his own region. The composition was written in collaboration with two avanguard singers from Bratislava Petr Matuszek and Markéta Dvořáková and premiered it in Katowice in the same year 2006.

\section{Czechs in Poland in the 19th and 20th Century and Their Influence on the Development of Polish National Music}

\section{Abstract}

The contribution of Czech composers to the development of the Polish national music begins in the era of the activity of Jan Stefani, the composer of musical set to Cracovians and Highlanders by Wojciech Bogusławski, considered the first Polish national opera. Further on are the achievements of Wilem Würffel as the creator of polonaises and fantasies based on Polish national melodies. Although after the anti-Russian uprising (1831), many Czech musicians still worked in Poland as music teachers, members of orchestras or choir directors, their participation in shaping the formation of Polish national music was rather niche. It was influenced by political reality, which was not favorable to the development

${ }^{17}$ Quoted after: Mieczysław Drobner, Opera i balet. W: Kultura muzyczna Polski Ludowej, ed. Józef Michał Chomiński, Zofia Lissa (Kraków 1957), 78. 
of Polish-Czech contacts, especially in the part of the country under Russian rule (here Czechs were seen as Russophiles). The impulse that increased interest in Czech music in Poland in the last decades of the 19th century was the awareness of its high position in Europe. The successes of Smetana and Dvořák's works discussed in foreign music press, prompted several Polish music activists to attempts to introduce them to national stages. However, it was only the beginning of the twientieth century when Czech national music was properly assessed by Polish composers. And here political factors played also a role - the "Czech Renaissance" in Polish musical thought was largely inspired by the events of the Prague Neo-Slav rally of 1908.

\section{Češi v Polsku v 19. a 20. století a jejich vliv na vývoj polské národní hudby}

\section{Abstrakt}

Vliv českých skladatelů na rozvoj polské národní hudby začíná v době činnosti Jana Stefaniho, tvůrce Krakowiacy i Górale podle Wojciecha Bogusławského, považovaného za první polskou národní operu. Dále jde o práce Wilema Würffela jako autora polonéz a fantazií založených na polských národních melodiích. Ačkoli po protiruském povstání (1831) v Polsku stále pracovalo mnoho českých hudebníků, a to v pozici učitelů hudby, členů orchestrů nebo sbormistrů, jejich účast na utváření polské národní hudby byla spíše malá. Tato skutečnost byla dána politickou realitou, která rozvoji polsko-českých vztahů nikterak nenahrávala, zejména v části země pod ruskou vládou (zde byli Češi považováni za rusofily). Impulsem, který zvýšil zájem o českou hudbu v Polsku v posledních desetiletích 19. století, bylo vědomí jejího vysokého postavení v kontextu celé Evropy. Úspěchy Smetanovy a Dvořákovy tvorby diskutované v zahraničním hudebním tisku přiměly několik polských hudebních aktivistů, aby se je pokusili představit na národních pódiích. K plnému uznání české národní hudby však došlo až na začátku 20. století. Politické faktory zde hrály rovněž důležitou roli - české národní obrození bylo polskými skladateli reflektováno zejména prizmatem událostí pražského neoslovanského sjezdu z roku 1908. 


\section{Keywords}

Polish-Czech cultural contacts; the reception od Smetana and Dvořák in Poland; national music; Central-European music culture of the 19th and 20th centuries

\section{Klíčová slova}

česko-polské kulturní kontaky; recepce Smetany a Dvořáka v Polsku; národní hudba; středoevropská hudba v 19. a 20. století

Magdalena Dziadek

Instytut Muzykologii Uniwersytetu Jagiellońskiego

magdalena.dziadek@uj.edu.pl 